\title{
Inhibitory Actions of Lupinifolin Isolated from Derris reticulata Stem against Carbohydrate-Digesting Enzymes
}

\author{
Pawitra Pulbutr, Pichnatcha Nantana, Surabot Suksabai, Chawannuch Mudjupa, Rattazart Denchai, \\ Sakulrat Rattanakiat, Taweesak Dhammaraj \\ Pharmaceutical Chemistry and Natural Product Research Unit, Faculty of Pharmacy, Mahasarakham University, Maha Sarakham, Thailand
}

\begin{abstract}
Background: Postprandial hyperglycemia is linked with the development of diabetic complications. Inhibition against the carbohydrate-digesting enzymes, specifically pancreatic $\alpha$-amylase and intestinal $\alpha$-glucosidase, delays carbohydrate digestion and subsides postprandial plasma glucose (PPG) levels. Objectives: This study aimed to examine the effects of lupinifolin, purified from Derris reticulata stem, a medicinal plant traditionally used for the treatment of diabetes mellitus, on in vitro $\alpha$-amylase and $\alpha$-glucosidase enzyme activities and enzyme kinetics. Subjects and Methods: The identification of the isolated phytochemical was performed using nuclear magnetic resonance-mass spectrometry (NMR-MS) spectrometry. In vitro pancreatic $\alpha$-amylase and $\alpha$-glucosidase activities and enzyme kinetics were determined using the enzymatic colorimetric methods. Results: The purified phytochemical was identified as lupinifolin from the NMR-MS spectrometry. The isolated lupinifolin produced a significant $\alpha$-amylase and $\alpha$-glucosidase inhibitory actions with the median inhibitory concentrations of $3.43 \pm 0.77$ and $56.29 \pm 11.64 \mu \mathrm{g} / \mathrm{mL}$, respectively. The study of enzyme kinetics showed that lupinifolin exhibited the mode of non-competitive and mixed enzyme inhibitions against $\alpha$-amylase and $\alpha$-glucosidase, respectively. Conclusion: The potent $\alpha$-amylase and $\alpha$-glucosidase inhibitory actions of lupinifolin derived from $D$. reticulata stem evidently suggest its potential use as an alternative for the control of PPG.

Key words: $\alpha$-amylase, $\alpha$-glucosidase, Derris reticulate, diabetes mellitus, lupinifolin

\section{SUMMARY}

- This research work is the first report of the potent inhibitory action of lupinifolin, isolated from Derris reticulata stem, against pancreatic $\alpha$-amylase, a crucial enzyme for starch digestion. The inhibitory action of lupinifolin against another essential carbohydrate-digesting enzyme, $\alpha$-glucosidase, was also demonstrated. The mode of non-competitive and mixed inhibitions against $\alpha$-amylase and $\alpha$-glucosidase, respectively, was also firstly described for the isolated lupinifolin in this study. The potent dual carbohydrate-digesting enzyme inhibitions of lupinifolin thus suggest its potential use as an alternative for the control of postprandial plasma glucose.
\end{abstract}

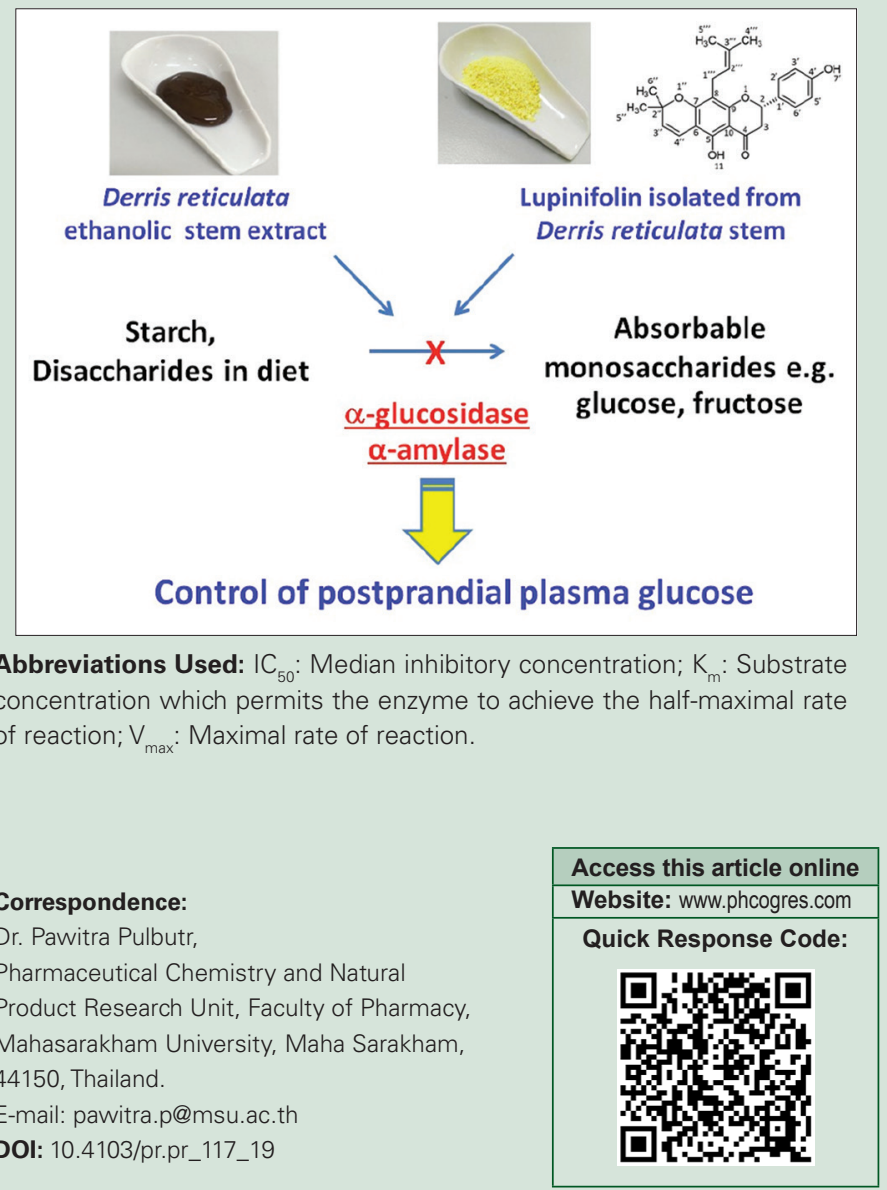

\section{INTRODUCTION}

The prevalence of diabetes mellitus, a major non-communicable disease, has been continuously increasing worldwide, especially in low- and middle-income countries. ${ }^{[1]}$ Poorly controlled plasma glucose can lead to many serious diabetic complications including myocardial infarction, cerebrovascular disease, renal failure, loss of vision, lower limb amputation, and nerve damage. ${ }^{[2]}$ These complications result in an increased risk of death and disability in patients with diabetes. Apart from its crucial impact on public health system, diabetes also brings substantial economic and social consequences. ${ }^{[1]}$ It has been documented that postprandial plasma glucose (PPG) is linked with the development of cardiovascular complications in diabetes. ${ }^{[3,4]}$ Postprandial hyperglycemia exerts its noxious effect on vascular endothelium via an induction of oxidative stress, which leads to endothelial dysfunction and pathogenesis of atherosclerosis. ${ }^{[5]}$ The importance of PPG control was evidenced in the Study to Prevent Non-Insulin-Dependent Diabetes
Mellitus (STOP-NIDDM) trial, in which patients with impaired glucose tolerance receiving acarbose, an $\alpha$-amylase and $\alpha$-glucosidase inhibitor, had significantly fewer cardiovascular events than those given placebo. ${ }^{[6]}$ Carbohydrate-digesting enzymes, specifically pancreatic $\alpha$-amylase and intestinal $\alpha$-glucosidase, play an important role in the regulation of PPG levels. Inhibition against the enzymes with acarbose, a clinically used

This is an open access journal, and articles are distributed under the terms of the Creative Commons Attribution-NonCommercial-ShareAlike 4.0 License, which allows others to remix, tweak, and build upon the work non-commercially, as long as appropriate credit is given and the new creations are licensed under the identical terms.

\section{For reprints contact: reprints@medknow.com}

Cite this article as: Pulbutr P, Nantana P, Suksabai S, Mudjupa C, Denchai R, Rattanakiat $\mathrm{S}$, et al. Inhibitory actions of lupinifolin isolated from Derris reticulata stem against carbohydrate-digesting enzymes. Phcog Res 2020;12:102-6. 
antidiabetic drug, delays carbohydrate digestion and subsides glucose excursion after a meal. ${ }^{[7]}$ The present treatment of diabetes includes both lifestyle modification (e.g., exercise and dietary control) and pharmacotherapy with antidiabetic agents. Although many antidiabetic agents with various mechanisms of action are currently available for the treatment of diabetes, the medicine accessibility is still limited in many diabetic patients living in developing countries due to their poor economic status. ${ }^{[8]}$ Several traditionally used medicinal plants are thus still valuable alternatives for diabetic treatment. A search for medicinal plants and their phytochemicals with effective carbohydrate-digesting enzyme inhibitory action is an ongoing field to provide alternatives for the control of PPG, particularly for underprivileged diabetic patients.

Derris reticulata Craib is a medicinal plant in family Leguminosae (subfamily Papilionoideae), which has been applied for several purposes in Thai traditional medicines. The extracts of $D$. reticulata stem were found to have several pharmacological actions such as antiinflammation, antibacterials, antioxidant as well as antidiabetes. ${ }^{\left[{ }^{-12]}\right.}$ Its stem has been included as one of ingredients in a Thai traditional herbal formula, named "Mathurameha," which is used for the treatment of diabetes mellitus. ${ }^{[13]}$ Local traditional medicine practitioners in some parts of Thailand have also employed the sole plant as an alternative diabetes treatment. The aqueous extract of $D$. reticulata stem had a significant blood glucose-lowering action in diabetic rats when given at the dose of $250 \mathrm{mg} / \mathrm{kg} /$ day for 15 days. ${ }^{[10]}$ The extract also exhibited various antidiabetic-related actions such as suppression against in vitro glucose absorption, pancreatic $\beta$-cell protection as well as moderate antioxidant activity. ${ }^{[10,11]}$ The $\alpha$-glucosidase inhibitory action of $D$. reticulata stem extracts prepared with various types of solvent, including hexane, chloroform, ethanol, and water was also documented in some studies. $^{[11,14,15]}$ Lupinifolin is a prenylated flavanone, which can be purified from some medicinal plants in family Leguminosae including D. reticulata stem. ${ }^{[16,17]}$ This flavanone exhibited many pharmacological actions including antidiarrheal, cytotoxic, and antimicrobial activities against bacteria, virus, and mycobacteria. ${ }^{[18-22]}$ It was recently reported that lupinifolin had an inhibitory action against $\alpha$-glucosidase enzyme. ${ }^{[15,23]}$ However, the inhibitory action of lupinifolin against pancreatic $\alpha$-amylase, a crucial enzyme for starch digestion, has not been evidenced. In addition, the mode of carbohydrate-digesting enzyme inhibitions of lupinifolin has not been established. This study thus aimed to investigate the actions of lupinifolin isolated from $D$. reticulata stem on $\alpha$-amylase and $\alpha$-glucosidase enzyme activities and enzyme kinetics.

\section{SUBJECTS AND METHODS}

\section{Isolation of lupinifolin from Derris reticulata stem}

The isolation of lupinifolin from $D$. reticulata stem was performed according to the method described by Chivapat et al. ${ }^{[24]}$ and Yusook et al. ${ }^{[22]}$ with some modifications. The stems of D. reticulata were obtained from the local herb store in Bangkok, Thailand. The authentication of the sample was conducted as described previously. ${ }^{[12]}$ The ground sample $(60 \mathrm{~g})$ was Soxhlet extracted with hexane $(400 \mathrm{~mL})$. The hot extract was filtered and subsequently heated at $65^{\circ} \mathrm{C}$ until the clear yellow extract was obtained. The extract was then partitioned with deionized water at $65^{\circ} \mathrm{C}$ and the hexane layer was collected. The hexane extract was evaporated using a rotary evaporator (Heidolph ${ }^{\circledR}$, Germany) until the turbid suspension was observed. The extract was left at room temperature for crystallization. The obtained lupinifolin crystals were kept at $-20^{\circ} \mathrm{C}$ until use. The $\%$ yield of the isolated lupinifolin was $0.9119 \%$.

\section{Identification of lupinifolin}

The identification of the isolated lupinifolin was elucidated by proton nuclear magnetic resonance $\left({ }^{1} \mathrm{H}-\mathrm{NMR}\right)$ and ${ }^{13}$ Carbon-NMR. ${ }^{1} \mathrm{H}-\mathrm{NMR}$ and ${ }^{13} \mathrm{C}$-NMR spectra were obtained at $300 \mathrm{MHz}$ using Bruker Avance
300 and Varian Mercury-300. Chemical shift values $(\delta)$ were given in ppm by referencing on the chemical shift of the deuterated solvent. Mass spectra were recorded on either a Thermo Finnigan or liquid chromatography MS (LCMS) Bruker micrOTOF.

\section{Alpha-amylase activity assay}

The $\alpha$-amylase activity assay was performed according to the method of Ali et al. ${ }^{[25]}$ with slight modifications. Briefly, $20 \mu \mathrm{L}$ of the sample was preincubated with $200 \mu \mathrm{L}$ of porcine pancreatic $\alpha$-amylase (10 unit $/ \mathrm{mL}$ ) at $25^{\circ} \mathrm{C}$ for $5 \mathrm{~min}$. Four hundred microliter of potato starch solution $(0.5 \% \mathrm{w} / \mathrm{v})$ and $180 \mu \mathrm{L}$ of deionized water were subsequently added into the mixture and incubated at $25^{\circ} \mathrm{C}$ for further $3 \mathrm{~min}$. An aliquot of the mixture $(200 \mu \mathrm{L})$ was then transferred to mix with $100 \mu \mathrm{L}$ of 3,5-dinitrosalicylic acid (DNS) color reagent (96 mM DNS and $5.31 \mathrm{M}$ sodium potassium tartrate in $2 \mathrm{M} \mathrm{NaOH}$ ) and then boiled at $85^{\circ} \mathrm{C}$ for $15 \mathrm{~min}$. The optical density (OD) of the mixture was measured at the wavelength of $540 \mathrm{~nm}$ by using an absorbance microplate reader (BMG LABTECH, Ortenberg, Germany). The amount of maltose released from $\alpha$-glucosidase-catalyzing reaction was used as an index of $\alpha$-amylase activity. The percentage of inhibition was calculated as the following equation: $\%$ inhibition $=([\mathrm{OD}$ of negative control] - [OD of sample]/[OD of negative control] $) \times 100$. Acarbose $(1000 \mu \mathrm{g} / \mathrm{mL})$ was used as a positive control in the experiment. The median inhibitory concentration $\left(\mathrm{IC}_{50}\right)$ was obtained from the concentration-response curve plotted using GraphPad Prism software version 6.0 (San Diego, California, USA).

\section{Alpha-glucosidase activity assay}

The $\alpha$-glucosidase activity assay was performed following the protocol of Elya et al. ${ }^{[26]}$ with some modifications. Briefly, a mixture of the sample $(10 \mu \mathrm{L}), 50 \mathrm{mM}$ phosphate buffer, $\mathrm{pH} 6.9(460 \mu \mathrm{L})$, and $0.15 \mathrm{unit} / \mathrm{mL}$ yeast $\alpha$-glucosidase enzyme $(125 \mu \mathrm{L})$ was prepared and incubated at $37^{\circ} \mathrm{C}$ for $5 \mathrm{~min} .250 \mu \mathrm{L}$ of $p$-nitrophenyl- $\alpha$-D-gl ucopyranoside ( $p$-NPG; $5 \mathrm{mM}$ ) and $155 \mu \mathrm{L}$ of phosphate buffer were added into the mixture and incubated for further $15 \mathrm{~min}$ at $37^{\circ} \mathrm{C}$. Subsequently, an aliquot of the mixture $(200 \mu \mathrm{L})$ was mixed with 400 $\mu \mathrm{L}$ of $\mathrm{Na}_{2} \mathrm{CO}_{3}(200 \mathrm{mM})$; the solution was then left at room temperature for further $5 \mathrm{~min}$. The OD of the final mixture was measured at the wavelength of $405 \mathrm{~nm}$. The amount of p-nitrophenol released from $\alpha$-glucosidase-catalyzing reaction was used as an index of $\alpha$-glucosidase activity. The percentage of inhibition was calculated as the following equation: \% inhibition $=([\mathrm{OD}$ of negative control $]-[\mathrm{OD}$ of sample $] /$ [OD of negative control] $) \times 100$. Acarbose $(500 \mu \mathrm{g} / \mathrm{mL})$ was used as a positive control in the experiment. The $\mathrm{IC}_{50}$ was obtained from the concentration-response curve plotted using GraphPad Prism software version 6.0 .

\section{Enzyme kinetics study}

The mode of enzyme inhibition was studied using the protocols of $\alpha$-amylase and $\alpha$-glucosidase activity assays described above. The reactions were conducted by various concentrations of the substrate, whereas the concentrations of the enzymes and lupinifolin were fixed. The Michaelis-Menten curve was plotted using least squares nonlinear regression in GraphPad Prism software version 6.0 to achieve the maximal rate of reaction $\left(\mathrm{V}_{\max }\right)$ and the Michaelis constant (substrate concentration which permits the enzyme to achieve the half-maximal rate of reaction $\left.\left[\mathrm{K}_{\mathrm{m}}\right]\right)$. The changes of $\mathrm{V}_{\max }\left(\Delta \mathrm{V}_{\max }\right)$ and $\mathrm{K}_{\mathrm{m}}\left(\Delta \mathrm{K}_{\mathrm{m}}\right)$ in the presence of the enzyme inhibitor were subsequently calculated by comparing the parameters with those obtained in the absence of the enzyme inhibitor. The experiments were performed in triplicate. 


\section{Statistical analysis}

The data of \% inhibition against enzyme activity were expressed as mean \pm standard error of the mean, while the data of the $\mathrm{IC}_{50}$ and the changes of $\mathrm{V}_{\max }$ and $\mathrm{K}_{\mathrm{m}}$ were shown as mean \pm standard deviation. The statistical analysis was performed using one-way analysis of variance followed by the Bonferroni post hoc test or Kruskal-Wallis test followed by Mann-Whitney U-test. The difference between the data was considered statistically significant when $P<0.05$.

\section{RESULTS}

\section{Identification of lupinifolin}

The obtained chemical was identified as lupinifolin (S)-5-hydroxy8-(4-hydroxyphenyl)-2,2-dimethyl-10-(3-methylbut-2-en-1-yl)-7,8dihydro-2H,6H-pyrano[3,2-g]chromen-6-one) $\left(\mathrm{C}_{25} \mathrm{H}_{26} \mathrm{O}_{5}\right)$ with light yellow crystal (\%yield $=0.9119 \%$ ). The characteristics of the isolated compound are described as follows: mp $113.7-115.5^{\circ} \mathrm{C} .{ }^{1} \mathrm{H}-\mathrm{NMR}(300$ $\mathrm{MHz}$, Chloroform-D) d 12.25 (s, 1H), 7.33 (d, J=8.51 Hz, 2H), 6.90 (d, $\mathrm{J}=8.59,2 \mathrm{H}), 6.65$ (d, J=9.99 Hz, 1H), 5.52 (d, J=10.00 Hz, 1H), 5.35 (dd, $\mathrm{J}=3.06,12.72 \mathrm{~Hz}, 1 \mathrm{H}), 5.16(\mathrm{t}, \mathrm{J}=7.38 \mathrm{~Hz}, 1 \mathrm{H}), 3.22(\mathrm{~d}, \mathrm{~J}=7.30 \mathrm{~Hz}, 2 \mathrm{H})$, 3.07 (dd, J=12.77, $17.13 \mathrm{~Hz}, 1 \mathrm{H}), 2.82$ (dd, J=3.16, $17.13 \mathrm{~Hz}, 1 \mathrm{H}), 1.67$ (s, 6H), 1.46 (d, J=4.31, 6H); ${ }^{13} \mathrm{C}-\mathrm{NMR}$ (300 MHz, Chloroform-D) d 21.48, 25.83, 28.31, 28.41, 43.15, 76.63, 77.05, 77.48, 78.20, 78.54, 102.67, $102.83,108.71,115.56,115.62,122.47,126.05,127.72,130.80,131.16$, $156.08,156.56,159.44,160.03$, 196.70; LC-MS (electrospray ionization) $407.1853[\mathrm{M}+\mathrm{Na}]$. The structures of lupinifolin were fully characterized by ${ }^{1} \mathrm{H}-\mathrm{NMR},{ }^{13} \mathrm{C}-\mathrm{NMR},{ }^{1} \mathrm{H}-{ }^{13} \mathrm{C}$ correlation Heteronuclear Multiple Quantum Coherence (HMCQ), Heteronuclear Multiple Bond Coherence (HMBC), Distortionless Enhancement by Polarization Transfer (DEPT) where their spectra were in agreement with the assigned structure.

\section{Alpha-amylase activity assay}

The isolated lupinifolin at the concentration of 50, 12.5, 5, 2.5, and $1 \mu \mathrm{g} / \mathrm{mL}$ produced a significant $\alpha$-amylase inhibitory action with the $\mathrm{IC}_{50}$ of $3.43 \pm 0.77 \mu \mathrm{g} / \mathrm{mL}(n=5)$ [Table 1]. Lupinifolin at concentration of $12.5 \mu \mathrm{g} / \mathrm{mL}$ caused a maximal inhibition of $75.85 \% \pm 2.27 \%$.

Acarbose (positive control) at the concentration of $1000 \mu \mathrm{g} / \mathrm{mL}$ significantly inhibited $\alpha$-amylase activity with $\%$ inhibition of $44.10 \%$ $\pm 1.15 \%(n=5)$.

\section{Alpha-amylase enzyme kinetics study}

From the Michaelis-Menten plot, lupinifolin at its approximate $\mathrm{IC}_{50}$ of $4 \mu \mathrm{g} / \mathrm{mL}$ caused a decrease in $\mathrm{V}_{\max }$ with no significant change in $\mathrm{K}_{\mathrm{m}}$ [Table 2 and Figure 1]. On the contrary, acarbose $(1000 \mu \mathrm{g} / \mathrm{mL})$ decreased both $\mathrm{V}_{\max }$ and $\mathrm{K}_{\mathrm{m}}$ [Table 2 and Figure 1].

\section{Alpha-glucosidase activity assay}

The isolated lupinifolin had a concentration-dependent inhibitory action against $\alpha$-glucosidase with the $\mathrm{IC}_{50}$ of $56.29 \pm 11.64 \mu \mathrm{g} / \mathrm{mL}(n=3)$ [Table 3]. Lupinifolin at the highest concentration tested $(250 \mu \mathrm{g} / \mathrm{mL})$ caused a maximal inhibition of $98.58 \% \pm 2.44 \%$.

Acarbose $(1000 \mu \mathrm{g} / \mathrm{mL})$, positive control, produced a significant $\alpha$-glucosidase inhibition with the $\%$ inhibition of $68.18 \pm 0.50(n=9)$.

\section{Alpha-glucosidase enzyme kinetics study}

The isolated lupinifolin at its $\mathrm{IC}_{50}(60 \mu \mathrm{g} / \mathrm{mL})$ caused changes of both $\mathrm{V}_{\max }$ and $\mathrm{K}_{\mathrm{m}}$ with a decrease in $\mathrm{V}_{\max }$ and an increase in $\mathrm{K}_{\mathrm{m}}$ from the Michaelis-Menten plot [Table 4 and Figure 2]. Acarbose $(500 \mu \mathrm{g} / \mathrm{mL})$ also changed the $\alpha$-glucosidase enzyme kinetics with an increase in $\mathrm{K}_{\mathrm{m}}$ and a slight decrease in $\mathrm{V}_{\max }$ [Table 4 and Figure 2].
Table 1: The percentage of inhibition of lupinifolin against pancreatic a-amylase activity

\begin{tabular}{lc}
\hline Concentration $(\mu \mathrm{g} / \mathrm{mL})$ & Percentage inhibition (mean \pm SEM) \\
\hline 50 & $74.97 \pm 1.77^{*}$ \\
12.5 & $75.85 \pm 2.27^{*}$ \\
5 & $69.48 \pm 3.47^{*}$ \\
2.5 & $44.84 \pm 1.93^{*}$ \\
1 & $20.54 \pm 3.52^{*}$ \\
0.5 & $6.99 \pm 2.02$ \\
0.25 & $5.70 \pm 2.78$ \\
0 & $0.00 \pm 0.00$ \\
\hline
\end{tabular}

${ }^{*} P<0.05$ when compared with negative control; One-way ANOVA followed by the Bonferroni post hoc test; $n=5$. ANOVA: Analysis of variance; SEM: Standard error of mean

Table 2: Enzyme kinetics study of lupinifolin and acarbose against pancreatic a-amylase $(n=4)$

\begin{tabular}{lcc}
\hline Test agents & $\Delta \mathrm{V}_{\max }($ mean $\pm \mathrm{SD})$ & $\Delta \mathrm{K}_{\mathrm{m}}$ (mean $\left.\pm \mathrm{SD}\right)$ \\
\hline Lupinifolin $(4 \mu \mathrm{g} / \mathrm{mL})$ & $-0.2712 \pm 0.0444$ & $-0.0065 \pm 0.0129$ \\
Acarbose $(1000 \mu \mathrm{g} / \mathrm{mL})$ & $-0.3046 \pm 0.0178$ & $-0.2041 \pm 0.0232$ \\
\hline
\end{tabular}

SD: Standard deviation

Table 3: The percentage of inhibition of lupinifolin against $\alpha$-glucosidase activity

\begin{tabular}{lc}
\hline Concentration $(\mu \mathrm{g} / \mathrm{mL})$ & Percentage inhibition (mean \pm SEM) \\
\hline 250 & $98.58 \pm 2.44^{*}$ \\
100 & $58.51 \pm 3.74^{*}$ \\
20 & $20.59 \pm 1.32^{*}$ \\
10 & $15.06 \pm 1.46^{*}$ \\
1 & $11.31 \pm 1.38^{*}$ \\
0.1 & $7.60 \pm 0.69$ \\
0 & $0.00 \pm 0.00$ \\
${ }^{*} P<0.05$ when compared with negative control; Kruskal-Wallis test followed by
\end{tabular}

Mann-Whitney U-test; $n=9$. SEM: Standard error of mean

Table 4: Enzyme kinetics study of lupinifolin and acarbose against a-glucosidase $(n=3)$

\begin{tabular}{lcc}
\hline Enzyme inhibitors & $\Delta \mathbf{V}_{\text {max }}($ mean $\pm S D)$ & $\Delta \mathrm{K}_{\mathrm{m}}($ mean $\pm \mathrm{SD})$ \\
\hline Lupinifolin $(60 \mu \mathrm{g} / \mathrm{mL})$ & $-0.2716 \pm 0.0520$ & $+0.2950 \pm 0.0709$ \\
Acarbose $(500 \mu \mathrm{g} / \mathrm{mL})$ & $-0.1422 \pm 0.0399$ & $+5.4917 \pm 1.3810$ \\
\hline
\end{tabular}

SD: Standard deviation

\section{DISCUSSION}

Pancreatic $\alpha$-amylase, located in the intestinal lumen, is a crucial enzyme for starch digestion into oligosaccharides. The obtained oligosaccharides are subsequently digested into absorbable monosaccharides by $\alpha$-glucosidase. Since starch is the main source of carbohydrate in the diet, both $\alpha$-amylase and $\alpha$-glucosidase enzymes are essential for dietary carbohydrate digestion. The potent inhibitory action of lupinifolin against pancreatic $\alpha$-amylase was firstly demonstrated here in this study with the $\mathrm{IC}_{50}$ of $3.43 \pm 0.77 \mu \mathrm{g} / \mathrm{mL}$. The isolated lupinifolin also produced a concentration-dependent inhibition against $\alpha$-glucosidase with the $\mathrm{IC}_{50}$ of $56.29 \pm 11.64 \mu \mathrm{g} / \mathrm{mL}$. The $\alpha$-glucosidase inhibiting potency of lupinifolin isolated in the current study was somewhat lower than that reported earlier by Issarachote and Joycharat (2015) $\left(\mathrm{IC}_{50}\right.$ of $11.22 \mu \mathrm{g} / \mathrm{mL}$ ). Lupinifolin is a prenylated flavanone with a good solubility in organic solvent, but it has a very low water solubility of $0.009 \mathrm{mg} / \mathrm{L}$, estimated from its octanol-water partition coefficient at $25^{\circ} \mathrm{C}$. ${ }^{[22]}$ Since lupinifolin has a remarkably low water solubility, it is critical to use the appropriate vehicle for lupinifolin dilution before adding it 


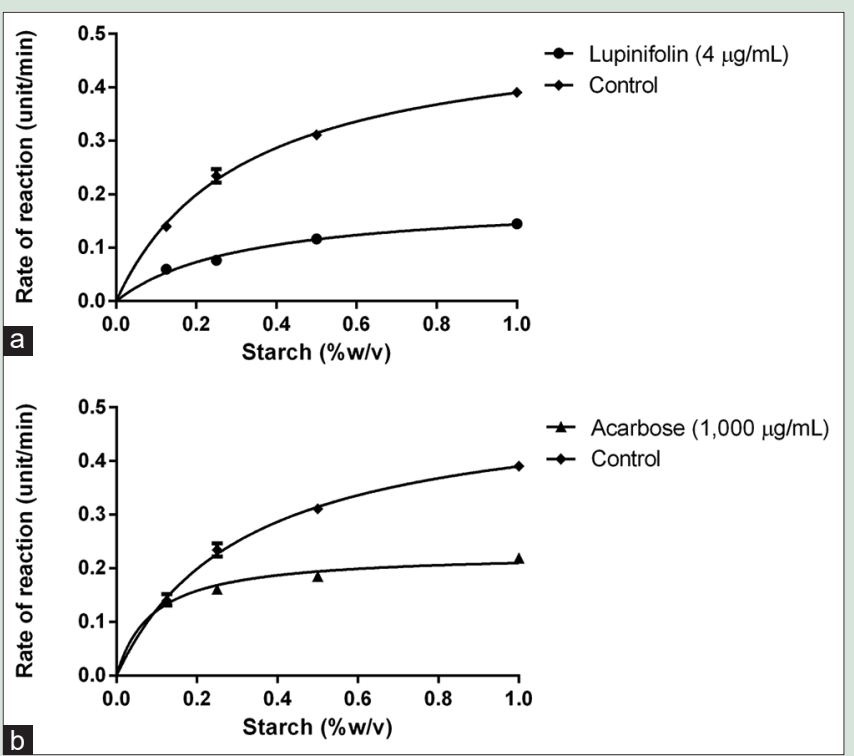

Figure 1: The Michaelis-Menten plot of the $\alpha$-amylase catalyzing reaction in the presence or absence of (a) lupinifolin $(4 \mu \mathrm{g} / \mathrm{mL})$ and (b) acarbose $(1000 \mu \mathrm{g} / \mathrm{mL})$. (Mean \pm standard deviation, $n=4)$

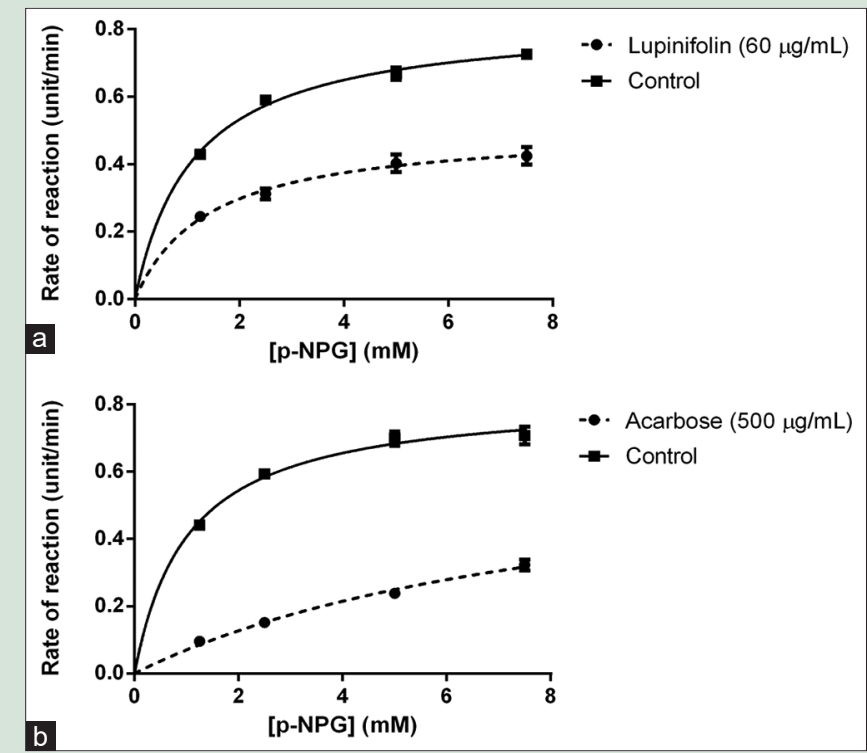

Figure 2: The Michaelis-Menten plot of the $\alpha$-glucosidase-catalyzing reaction in the presence or absence of (a) lupinifolin $(60 \mu \mathrm{g} / \mathrm{mL}$ ) and (b) acarbose $(500 \mu \mathrm{g} / \mathrm{mL})$. (Mean \pm standard deviation, $n=3$ ) into the aqueous buffer. To avoid precipitation in aqueous media, Yusook et al. (2017) suggested that lupinifolin should be prepared with $0.1 \mathrm{M}$ $\mathrm{NaOH}$. This basic solution was thus used as a vehicle for lupinifolin in the present work, whereas dimethyl sulfoxide was indicated as a vehicle for lupinifolin in the study of Issarachote and Joycharat. ${ }^{[15]}$ A difference in the vehicle used for lupinifolin dilution may possibly cause a variation in its inhibitory action against the enzyme. In addition, dissimilarity in enzyme activity between studies can also lead to a slight difference in the inhibitory action of lupinifolin. Nonetheless, both the studies indicated a potent $\alpha$-glucosidase inhibition of $D$. reticulata-derived lupinifolin with relatively low $\mathrm{IC}_{50}$ in ranges of double-digit $\mu \mathrm{g} / \mathrm{mL}$.

It was reported that acarbose produced an inhibitory action against both $\alpha$-amylase and $\alpha$-glucosidase enzymes with the $\mathrm{IC}_{50 \text { s }}$ of $258 \pm 17$ and $280 \pm 19 \mu \mathrm{g} / \mathrm{mL}$, respectively. ${ }^{[27]}$ The potency of lupinifolin against both $\alpha$-amylase and $\alpha$-glucosidase was thus apparently higher than those of acarbose, which is clinically used for a control of PPG in Type 2 diabetic patients. Postprandial hyperglycemia has been found to be linked with chronic complications, especially cardiovascular diseases in patients with diabetes. ${ }^{[3-5,28]}$ From the STOP-NIDDM trial, it was shown that the risk of cardiovascular events was significantly lower in patients with impaired glucose tolerance taking acarbose. ${ }^{[6]}$ A meta-analysis on the use of acarbose in Type 2 diabetic patients also showed a reduced risk of myocardial infarction. ${ }^{[29]}$ However, a clinical use of $\alpha$-glucosidase inhibitor for controlling PPG is still limited in some areas due to its relatively high cost comparing to other anti-diabetic agents such as metformin and sulfonylureas. ${ }^{[30]}$ The current findings of potent $\alpha$-amylase and $\alpha$-glucosidase inhibitory actions of lupinifolin isolated from $D$. reticulata stem may potentially improve antidiabetic drug accessibility regarding $\alpha$-amylase and $\alpha$-glucosidase inhibitors. Since various types of carbohydrates (e.g., starch, oligosaccharides, and disaccharides) can be found in a normal diet, a digestion of dietary carbohydrate would be suppressed more effectively by an agent inhibiting both $\alpha$-amylase and $\alpha$-glucosidase enzymes. Thus, the dual enzyme inhibitory actions of lupinifolin potentially imply its advantage in the regulation of PPG. Nonetheless, further in vivo study, specifically oral starch-tolerance and oral sucrose-tolerance tests, is still necessarily required to verify their actions in the body. In addition, a chronic toxicity test is also needed since long-term treatment is committed to the control of PPG in patients with diabetes. Nonetheless, it was reported from the animal study that lupinifolin at the highest dose tested of $5 \mathrm{~g} / \mathrm{kg}$ did not produce any acute toxic effects and no subacute toxic effect was detected at the dose of $60 \mathrm{mg} / \mathrm{kg} /$ day (given for 28 days). ${ }^{[24]}$

The results from the enzyme kinetics study indicated that lupinifolin acted as a non-competitive inhibitor against $\alpha$-amylase with a decrease in $\mathrm{V}_{\max }$ and no significant change in $\mathrm{K}_{\mathrm{m}}$. Non-competitive inhibitor binds to allosteric site of the enzyme and impedes the binding of substrate to the active site by inducing conformational change. ${ }^{[31]}$ Meanwhile, lupinifolin behaved as a mixed inhibitor against $\alpha$-glucosidase since it caused a decrease in $\mathrm{V}_{\max }$ and an increase in $\mathrm{K}_{\mathrm{m}}$. An increase in $\mathrm{K}_{\mathrm{m}}$ indicates that a mixed enzyme inhibitor could decrease the substrate binding affinity to the enzyme. This is dissimilar to the action of a non-competitive inhibitor, which does not cause any change in $\mathrm{K}_{\mathrm{m}}$. Unlike a competitive inhibitor, the inhibitory actions of both non-competitive and mixed inhibitors do not depend on a concentration of available substrate. ${ }^{[31]}$ Both non-competitive and mixed inhibitors restrain a maximal rate of reaction to a lower level even in the presence of higher substrate concentration. A sustainably low level of carbohydrate digestion would be considerably expected at any larger extent of carbohydrate consumed. This advantage of non-competitive and mixed enzyme inhibitors may be crucial in clinical practice since dietary control is one of the main obstacles frequently found in the management of Type 2 diabetes. ${ }^{[32]}$ However, a higher risk of gastrointestinal adverse events, as a consequence of undigested carbohydrate accumulation, may be observed during the use of these types of enzyme inhibitor.

In addition to its inhibition against $\alpha$-glucosidase, it was documented that the crude $D$. reticulata aqueous extract further possessed other antidiabetic actions, including pancreatic $\beta$-cell protection and suppression of glucose absorption. ${ }^{[10,11]}$ It is still not known whether the isolated lupinifolin can exhibit those antidiabetic mechanisms of action. Nevertheless, the potent $\alpha$-amylase and $\alpha$-glucosidase inhibitory actions of lupinifolin derived from $D$. reticulata stem were demonstrated in this study thus firmly support its potential use as an alternative for the treatment of diabetes mellitus, particularly for the control of PPG. 


\section{CONCLUSION}

Lupinifolin, isolated from $D$. reticulata stem, significantly inhibited $\alpha$-amylase and $\alpha$-glucosidase activities with the $\mathrm{IC}_{50 \text { s }}$ of $3.43 \pm 0.77$ and $56.29 \pm 11.64 \mu \mathrm{g} / \mathrm{mL}$, respectively. The enzyme kinetics study showed that lupinifolin exhibited the mode of non-competitive and mixed inhibitions against $\alpha$-amylase and $\alpha$-glucosidase, respectively.

\section{Financial support and sponsorship}

This project is financially supported by the Faculty of Pharmacy, Mahasarakham University research grant (Grant number S5/2562).

\section{Conflicts of interest}

There are no conflicts of interest.

\section{REFERENCES}

1. World Health Organization. Global Report on Diabetes. Geneva, Switzerland: World Health Organization Press; 2016.

2. American Diabetes Association. 2. Classification and diagnosis of diabetes: Standards of medical care in diabetes-2019. Diabetes Care 2019;42:S13-28.

3. Ceriello A. Postprandial hyperglycemia and diabetes complications: Is it time to treat? Diabetes 2005;54:1-7.

4. O'Keefe JH, Bell DS. Postprandial hyperglycemia/hyperlipidemia (postprandial dysmetabolism) is a cardiovascular risk factor. Am J Cardiol 2007;100:899-904

5. Avogaro A. Postprandial glucose: Marker or risk factor? Diabetes Care 2011;34:2333-5

6. Chiasson JL, Josse RG, Gomis R, Hanefeld M, Karasik A, Laakso M, et al. Acarbose treatment and the risk of cardiovascular disease and hypertension in patients with impaired glucose tolerance: The STOP-NIDDM trial. JAMA 2003;290:486-94.

7. Kennedy M, Masharani U. Pancreatic hormones and antidiabetic drugs. In: Katzung BG, editor. Basic and Clinical Pharmacology. New York: McGraw-Hill; 2018. p. 747-71.

8. International Diabetes Federation. Access to medicines and supplies for people with diabetes. Brussels (Belgium): International Diabetes Federation; 2016.

9. Vongnam T, Wittayalertpanya S, Raungrungsi N, Limpanasithikul W. Inhibitory effect of Derris reticulata ethanol extract on LPS-induced macrophage activation. Asian Biomed 2013;7:89-95

10. Kumkrai P, Kamonwannasit S, Chudapongse N. Cytoprotective and anti-diabetic effects of Derris reticulata aqueous extract. J Physiol Biochem 2014;70:675-84.

11. Kumkrai $P$, Weeranantanapan $O$, Chudapongse N. Antioxidant, $\alpha$-glucosidase inhibitory activity and sub-chronic toxicity of Derris reticulata extract: Its antidiabetic potential. BMC Complement Altern Med 2015;15:35

12. Pulbutr $P$, Rattanakiat $S$, Phetsaardeiam N, Modtaku $P$, Denchai $R$, Jaruchotikamol A, et al. Anticariogenic activities of Derris reticulata ethanolic stem extract against Streptococcus mutans. Pak J Biol Sci 2018;21:300-6.

13. Chayarop K, Peungvicha $P$, Temsiririrkkul R, Wongkrajang $Y$, Chuakul W, Rojsanga P. Hypoglycaemic activity of Mathurameha, a Thai traditiona herbal formula aqueous extract, and its effect on biochemical profiles of streptozotocin-nicotinamide-induced diabetic rats. BMC Complement Altern Med 2017; 17:343

14. Riyachan S. Comparison of antioxidant and $\alpha$-glucosidase inhibitory activities among three different Derris reticulata craib. Stem extracts. Nakhon Ratchasima, Thailand: M.Sc. Thesis, School of Pharmacology, Suranaree University of Technology; 2014

15. Issarachote P, Joycharat N. Alpha-glucosidase inhibitory activity of the wood of
Derris reticulata Craib. Proceedings of the $1^{\text {st }}$ National Conference in Traditional Thai Medicine: NC-TTM1; 2015 Dec 23-25. Songkla, Thailand. Songkla: Faculty of Traditional Thai Medicine, Prince of Songkla University; 2015.

16. Mahidol C, Prawat H, Ruchirawat S, Lihkitwitayawuid K, Lin LZ, Cordell GA Prenylated flavanones from Derris reticulata. Phytochemistry 1997;45:825-9.

17. Mahidol $\mathrm{C}$, Prawat $\mathrm{H}$, Kaweetripob W, Ruchirawat S. Two new pyranoflavanones from the stems of Derris reticulata. Heterocycles 2002;57:1287-92.

18. Soonthornchareonnon N, Ubonopas L, Kaewsuwan S, Wuthi-Udomlert M Lupinifolin, a bioactive flavonone from Myriopteron extensum (Wight) K. Schum. stem. Thai J Phytopharmacy 2004;11:19-28.

19. Wisetsutthichai S, Techamahamaneerat S, Junyaprasert V Soonthornchareonnon N. Gel preparation development from Derris reticulata Craib. extract as an anti-herpes simplex drug. Thai J Phytopharmacy 2005;12:11-22.

20. Joycharat N, Boonma C, Muangnua S, Poorisakpaisal P, Suwannawong C, Limsuwan S. Anti-Streptococcus mutans activity of lupinifolin from ethanol extract of Albizia myriophylla Benth. KKU Sci J. 2014;42: 806-19.

21. Prasad SK, Laloo D, Kumar M, Hemalatha S. Antidiarrhoeal evaluation of root extract, its bioactive fraction, and lupinifolin isolated from Eriosema chinense. Planta Med 2013;79:1620-7.

22. Yusook K, Weeranantanapan O, Hua Y, Kumkrai P, Chudapongse N. Lupinifolin from Derris reticulata possesses bactericidal activity on Staphylococcus aureus by disrupting bacterial cell membrane. J Nat Med 2017;71:357-66.

23. Issarachot $P$, Sangkaew W, Sianglum W, Saeloh D, Limsuwan S, Voravuthikunchai SP, et al. $\alpha$-Glucosidase inhibitory, antibacterial and antioxidant activities of natural substances from the wood of Derris reticulata Craib. Nat Prod Res 2019. p. 1-8. doi: 10.1080/14786419.2019.1678610.

24. Chivapat S, Chavalittumrong P, Attawish A, Soonthornchareonnon N. Toxicity study of lupinifolin from stem of Derris reticulata Craib. J Thai Trad Altern Med 2009;7:146-55

25. Ali $H$, Houghton PJ, Soumyanath A. $\alpha$-Amylase inhibitory activity of some Malaysian plants used to treat diabetes; with particular reference to Phyllanthus amarus. J Ethnopharmacol 2006;107:449-55.

26. Elya B, Basah K, Mun'im A, Yuliastuti W, Bangun A, Septiana EK. Screening of $\alpha$-glucosidase inhibitory activity from some plants of Apocynaceae, Clusiaceae Euphorbiaceae, and Rubiaceae. J Biomed Biotechnol 2012;2012:1-6. doi: 10.1155/2012/281078.

27. Poovitha S, Parani M. In vitro and in vivo $\alpha$-amylase and $\alpha$-glucosidase inhibiting activities of the protein extracts from two varieties of bitter gourd (Momordica charantia L.). BMC Complement Altern Med 2016;16 Suppl 1:185.

28. Cavalot F, Pagliarino A, Valle M, Di Martino L, Bonomo K, Massucco P, et al. Postprandial blood glucose predicts cardiovascular events and all-cause mortality in Type 2 diabetes in a 14-year follow-up: Lessons from the San Luigi Gonzaga Diabetes Study. Diabetes Care 2011;34:2237-43.

29. Hanefeld M, Cagatay M, Petrowitsch T, Neuser D, Petzinna D, Rupp M. Acarbose reduces the risk for myocardial infarction in Type 2 diabetic patients: Meta-analysis of seven long-term studies. Eur Heart J 2004;25:10-6.

30. Gu S, Tang Z, Shi L, Sawhney M, Hu H, Dong H. Cost-minimization analysis of metformin and acarbose in treatment of Type 2 diabetes. Value Health Reg Issues 2015;6:84-8.

31. Strelow J, Dewe W, Iversen PW, Brooks HB, Radding JA, McGee J, et al Mechanism of action assays for enzymes. Bethesda (MD): National Library of Medicine (US). c1999. Available from: https://www.ncbi.nlm.nih.gov/books/ NBK92001/[Last updated on 2012 Oct 01; Last accessed on 2019 Apr 01].

32. Forouhi NG, Misra A, Mohan V, Taylor R, Yancy W. Dietary and nutritional approaches for prevention and management of Type 2 diabetes. BMJ 2018;361:k2234. 